\title{
A Covid19 járvány okozta életmódbeli változások hatásai az óvodahasználókra - Óvodapedagógusok és szülők tapasztalatainak áttekintése
}

\author{
Villányi Györgyné \\ Magyar Pedagógiai Társaság
}

\begin{abstract}
Absztrakt
A Magyar Pedagógiai Társaság Kisgyermeknevelési Szakosztály vezetésével széles körü online felmérés készült 2020. első felében az életbe lépett óvodai bezárásokkal kapcsolatos változások feltérképezése érdekében. A kérdőíveket Bakonyi Anna, Kosztel Krisztina és Villányi Györgyné Jutka készítették. A kérdések tartalmaztak statisztikai adatkérést, online óvodai nevelési tervezést, módszertani és megvalósítási módokat, valamint kapcsolattartási, szervezési lehetőségek feltárását is. Az óvodapedagógusoknak és a szülőknek készült kérdőívekben arra kerestük a választ, hogy hogyan élték meg a karanténban, a virtuális térben működő sajátos helyzetet. Kíváncsiak voltunk arra, milyen tapasztalatokkal, érzésekkel lettek gazdagabbak, vagy éppen szegényebbek, s melyek azok a pozitív tudástartalmak, melyek átvihetők, sőt átviendők későbbre is, a mindennapi óvodai életbe. A Facebookon 2020. május 12-e és június 09-e között kiküldött kérdőíveket 1298 óvodapedagógus töltötte ki . A szülők 2020. május 11-e és június 03-a közötti időszakban válaszoltak a kérdésekre, 681-an.
\end{abstract}

Kulcsszavak: „távnevelés” óvodáskorban, kapcsolatok sokfélesége, életmódbeli változások

\section{Bevezetés}

A „Maradj otthon, otthonról dolgozz!” felhívás sok új feladat elé állította a kisgyermekneveléssel foglalkozó felnőtteket.

Mi a feladata ebben a helyzetben az óvodának, az óvodapedagógusnak? A megváltozott körülmények miatt néhol kényszerből és néha tehetetlenségből vagy éppen okszerű tisztán látás és helyismeret alapján sokféle megoldás született. A kérdésre mindenki másképpen válaszolt , és másképpen is valósította meg, mint ahogyan eltervezte.

A kérdőívek összeállítása előtt helyi problématérképek ismeretében elemeztük a tennivalókat. Mindezek alapján a következő kérdésekre kerestük a 
válaszokat: Ha a szülő tanácsot szeretne kérni, mikor, mivel és mennyi ideig érheti el az óvodapedagógust? Milyen szolgáltatásra van szüksége a szülőnek - nevelési tanácsadás vagy problémamegoldás, vagy meghatározott időben egy kis mentesítésre , vagyis "gyermekmentes" időre van szüksége a szülönek a mindennapi háztartási tevékenységei megoldása érdekében vagy az éppen aktuális távmunkája miatt? A legfontosabb kérdés, mire van szüksége a gyereknek ebben az időszakban? Mit tudunk számára nyújtani, hogy ne sérüljön, és a fejlődése ne akadjon meg a megváltozott életmód következményeként. Mi tehetünk, hogy továbbra is érzelmi biztonságban jól érezze magát. " - A családokat és a tudományos mühelyeket e nehéz időszakban legfőképpen hasonló kérdések foglalkoztatták .

$\mathrm{Az}$ óvodapedagógusok az online továbbképzések során megtanultak tervezni, csoport naplót készíteni, portfóliót összeállítani számítógépen, a gyermeki fejlődést nyomon követését grafikonokkal szemléltetni. A pedagógusoknak szánt felkészítések folyamán újraértelmezett játékokat is megismertek, illetve felhívtuk a figyelmet, hogy részképeségfejlesztő játékok sokasága található az interneten, érdemes tágítani a tudáshorizontjukat. Sok óvodában úgy használják a csoportszobában a számítógépet, mint „egy játék a többi között", amin mesét, énekes tevékenységeket láthatnak, mennyiségi és környezetismereti tevékenységek színes tárházával foglalkoznak a gyerekek. A köztudatban gyorsan elterjedt a "távoktatás” fogalom , amely azonban nem teljesen fedi a gyermekek iskolai tanulásával kapcsolatos tennivalók tárházát. Ugyanez vonatkozik a "távnevelés” kifejezésre, mindannyian ebben a sajátos időszakban ismerkedtünk a kifejezésekkel. A távoktatás fogalma és gyakorlata a felnőttképzés terén - a felsőoktatásban és az egész életen át tartó felnőttkori tanulás világában évtizedek óta él. A következő szakirodalmi idézet is ezt támasztja alá. „(A távoktatás során) a tanulásvezetési - irányítási funkciók megváltoznak, a pedagógus szerep is. A tutorok egyszerre képesek többek tanulását vezetni, irányítani ugyanakkor külön-külön egyéni útmutatást adni." (Csoma, 2014, p. 6). A tanuló és tanítója közötti térbeli és időbeli távolsági létre és ennek többféle megvalósítási módjaira hívja fel a figyelmet kötetében Kovács Ilma. „Távoktatás szempontjából azonban nem csak az a fontos, hogy mindenki hozzáférjen a megfelelő modern eszközhöz (...), hanem hogy egyrészt a pedagógiai szükségletek megfelelően adaptálják azokat, másrészt pedig, hogy ezek az eszközök, módszerek az adaptáció után megfelelö módon illeszkedjenek a rendszerbe." (Kovács, 1996, p. 50).

A nevelés közvetlen ráhatás útján valósul meg, növel, fejleszt, alakít, óvodás korban pedig a minta, a mintaadás és a minta átvétel jelent elsősorban tanulási folyamatot. Mindezek az online térben kicsit másképpen alakulnak, más hatásrendszerrel bírnak, mint a közvetlen valóságos térben. Ráadásul a „távnevelési” feladatok között sok olyan tevékenység, tennivaló válik másfajta módon megvalósíthatóvá, amely nem is neveléshez tartozik, csak kiegészíti a nevelési folyamatot, vagyis segítheti, vagy éppen gátolhatja a nevelési célok megvalósítását. Ide tartozik egyebek között a szülői nevelési tanács- 
adások tartalma, a Coviddal kapcsolatos rendelkezésekkel járó szabályok óvodai rendbe való beillesztése.

$\mathrm{Az}$ iskoláskor előtti nevelésben az életkörülményeket érintő változások okozta tartalmak következményei megjelentek a mindennapokban és azonnali megoldásokat igényeltek. Az intézményvezetők körében, a helyi nevelőtestületi vitákban, cikkekben, szakmai körökben új témák, feladatok köré épített lázas munka folyt. Kiemelten a kreatív óvodapedagógusok ötleteire épített fejlesztés, pedagógiai módszerek kimunkálása került előtérbe. Az óvodai honlapokon, óvodapedagógusi levelezések során kerültek felszínre a jó, vagy kevésbé sikeresnek tartott módszerek, eszközök, ötletek, megoldások.

Ezért gondoltuk, hogy egy szakmai civil szervezetben beindított kutatással megpróbáljuk felmérni a valós helyzetet, és megvizsgálni, mire van szükségükaz óvodahasználóknak: az óvodapedagógusoknak, a szülőknek és a gyerekeknek.

A felmérés során szerzett adatok számosságáról: óvodapedagógusi kérdések száma: 51, óvodapedagógusi írásos kiegészítő vélemények száma: 2456, szülői kérdések száma: 54, szülői írásos kiegészítő vélemények száma: 822. Ezek a számok azt igazolják, hogy a gyerekek nevelésével foglalkozó felnőttek úgy érezték beszélniük kell. El kell mondani véleményüket a kialakult helyzetek megoldási módjairól. A kérdőívben megfogalmazott válaszaikban közzé tudták tenni problémáikat, és a kérdésekre adott válaszok közben maguk is szembesültek a megoldási módokkal: mit tettek, mit éreztek és mit tapasztaltak, mivel a megvalósítók ők maguk voltak. Az adatgyüjtés során örömmel láttuk a gyors válaszadásokat, megdöbbent érdeklődéssel olvastuk a tartalmakat. A felmérés kérdéseit úgy állítottuk össze, hogy egyrészt minél több információt kapjunk a megváltozott helyzetben szervezett tevékenységek tartalmáról, a feladatok eredményességeiről vagy a kudarcokról, valamint kíváncsiak voltunk arra is, hogy ki hogyan élte meg a kialakult új helyzeteket. Az óvodapedagógusok és a szülők kaptak azonos kérdéseket is, hogy összehasonlító elemzéssel tudjunk választ keresni a partneri együttnevelés eredményesebbé tétele érdekében. Arra is gondoltunk, hogy keressük azokat a módszereket, eszközöket, melyek a megváltozott életmódhoz igazodva a fejlesztést is szolgálhatják a gyerekek fejlődésének segítése érdekében.

A kérdések közzététele a neten valósult meg, a Magyar Pedagógiai Társaság (MPT) Kisgyermeknevelési Szakosztály tagjai segítségével, amelyeket a különböző Facebook- csoportokban terjesztettünk .

Szakosztályunkból dr. Bakonyi Anna és Kosztel Krisztina a felmérés utáni időszakban készült külön tanulmányukban az elméleti tézisek mellett, megvalósítható gyakorlati ötleteket, tanácsokat adtak az online óvodai jelenlét megvalósításhoz. Online lehetöségek az óvodában, túl a karantén időszakán (Bakonyi \& Kosztel, 2020) címü írásból is látszik, hogy nem pusztán a gyors megoldások foglalkoztatták a szerzőket, hanem az is, hogy van-e olyan tapasztalati háttér és lett-e igény és képesség arra, hogy egy új, eddig csak csírájában lévő pozitív tudást az óvodapedagógusok „átvigyenek” a pandémiás helyzet utáni állapotra is. 


\section{A felmérés adatainak bemutatása és elemzése}

\section{A felmérés települési mutatói}

A települési adatokat összesítve megállapítható, minden település típus megfelelően képviselt a felmérésben.

\section{1. táblázat}

Településadatok

\begin{tabular}{|l|c|c|}
\hline települések neve & $\begin{array}{c}\text { szülők lakhelye } \\
(\mathbf{N}=\mathbf{6 8 1})\end{array}$ & $\begin{array}{c}\text { óvodák telephelye } \\
\mathbf{( N = 1 2 9 8})\end{array}$ \\
\hline fóváros & $26,9 \%$ & $23 \%$ \\
\hline nagyváros & $11,1 \%$ & $13 \%$ \\
\hline város & $35,9 \%$ & $42 \%$ \\
\hline falu & $26,1 \%$ & $22 \%$ \\
\hline
\end{tabular}

A kérdésekre a válaszok legtöbbje városokból érkezett, érdekes módon a nagyvárosokból jóval kevesebben voltak aktívák. A fővárosi és a falui szülői válaszok aránya (26,9\% és $26,1 \%)$, valamint az óvodapedagógusi válaszok aránya ( $23 \%$ és $22 \%$ ) egyaránt közeli értékeket mutat. Az adatok alapján arra lehet következtetni, hogy a válaszadók véleményére oda kell figyelnünk, mert lefedik a települési jellemzőket, valamint a kérdésekre adott válaszok konkrét tényeket közölnek.

\section{A válaszadók körének adataiból kiemelések}

Az életkori táblázat megdöbbentő, és komoly problémákra világít rá. Kiemelten a táblázat első négy sora mutat meglepően alacsony arányokat a fiatalabb óvodapedagógusok esetében. A szülők körében a 31- 40 éves korosztály válaszadási aránya a legmagasabb.

\section{2. táblázat}

A válaszoló óvodapedagógusok és szülók életkori adatai

\begin{tabular}{|c|c|c|}
\hline életkori szakaszok & óvodapedagógusok & szülők \\
\hline $20-25$ & $5,7 \%$ & $7 \%$ \\
\hline $26-30$ & $6,3 \%$ & $9,8 \%$ \\
\hline $31-35$ & $6,1 \%$ & $24,7 \%$ \\
\hline $36-40$ & $6,8 \%$ & $33,1 \%$ \\
\hline $41-45$ & $13,3 \%$ & $20,5 \%$ \\
\hline $46-50$ & $19,9 \%$ & $6 \%$ \\
\hline 50 felett & $41,9 \%$ & $5 \%$ \\
\hline
\end{tabular}


Miért a legmagasabb az 50 éven felüli óvodapedagógusok válaszadási aránya (41,9\%)? Mi lehet az oka, hogy a 40 éven aluli óvodapedagógusok válaszadási köre 6,8\% alatti értékeket mutat? A legtöbb válaszadó óvodapedagógus (41,9\%) 50 éven felüli és ha ehhez 46-50 éves korosztályt (19,9\%) hozzáadjuk, akkor azt mondhatjuk, hogy a válaszadó óvodapedagógusok több mint 69, 8\%-a 46 éven felüli.

Ezekre a kérdésekre ad választ a következő táblázat, amely bemutatja a jelenleg aktív óvodapedagógusként dolgozók életkori korfáját.

3. táblázat

Óvodapedagógusok életkori megoszlása. KIR alkalmazotti nyilvántartás (2021.05.10.)

\begin{tabular}{|c|c|c|}
\hline életkori szakaszok & óvodapedagógusok & óvodapedagógusok \\
\hline $20-25$ & 1611 & $5,4 \%$ \\
\hline $26-30$ & 2126 & $7,4 \%$ \\
\hline $31-35$ & 2527 & $8,5 \%$ \\
\hline $36-40$ & 2934 & $9,9 \%$ \\
\hline $41-45$ & 3777 & $12,8 \%$ \\
\hline $46-50$ & 4736 & $16,1 \%$ \\
\hline 50 felett & 11673 & $39,7 \%$ \\
\hline
\end{tabular}

Ezek az adatok indokolják a válaszadói arányokat. 20-35 éves korosztály az egyötöde az óvodapedagógusoknak. A 46 éven felüliek száma pedig 15409 fó, vagyis az óvodapedagógusok több mint fele, vagyis 55, 8\%.

Tovább elemezve az adatokat megállapítható, hogy bizony az óvodapedagógusi társadalomban az 51- 58 éves korosztály a legnépesebb, vagyis (9006 fö, 30,6\%) aktív óvodapedagógus dolgozik az óvodákban. Az 59- 64 éves kort elért dolgozók száma (2379 fö, 8\%) majdnem azonos a 31- 35 éves korosztályt képviselők számával (2527 fő, 8,5\%).

Ezek az adatok fényesen igazolják, hogy sok szükséges (lenne) változásokat eszközölni, a fiatal óvodapedagógusokat a pályára vonzani, mert a jelenlegi óvodapedagógus- állomány hosszabb távon nem oldja meg az iskoláskor előtti nevelés minőségi megvalósítását, néhány év múlva katasztrofális helyzeteket fog okozni a társadalomban, hiszen az óvodahálózat országos szinten lefedi az igényeket, de képzett óvodapedagógus nélkül nem működik.

A szülői oldalon 31 és 45 évesek vettek részt legaktívabban a felmérésben, a válaszadók több mint $2 / 3$-ad része (78,3\%). A nevelőpartneri kapcsolatok építése, javítása érdekében egyaránt érdemes elemezni, feldolgozni és elfogadni tapasztalataikat, javaslataikat.

A következő táblázat a szülők iskolai végzettségét mutatja be. A válaszadók között legmagasabb arányban vannak a felsőoktatásban és középfokon végzettek. 


\section{4. táblázat}

A kutatásban részt vevő szülők végzettségi aránya

\begin{tabular}{|l|c|c|}
\hline \multicolumn{1}{|c|}{ Szülők iskolai végzettsége } & N & $\%$ \\
\hline föiskola, egyetem & 372 & $55,3 \%$ \\
\hline középiskola & 205 & $30,5 \%$ \\
\hline szakiskola & 61 & $9,1 \%$ \\
\hline 8 általános & 30 & $4,1 \%$ \\
\hline 8 általános alatti végzettség & 5 & $0,7 \%$ \\
\hline
\end{tabular}

Sajnos az online térbeli kapcsolatokban a tudásigényü tevékenységek terén lemaradnak az alacsonyabb iskolai végzettséggel rendelkezők, ez a leszakadás tovább növekszik majd a jövőben. Ezért szükséges az alapfokú képzést nyújtó intézményekben céltudatosabb kompetenciafejlesztést megvalósítani (kommunikáció, IKT) , hiszen a jövő társadalmában a kapcsolati háló erősítése érdekében a tudás fontossága felértékelődik.

\section{Az online óvodai nevelés megvalósításával kapcsolatos vélemények}

Az óvodapedagógusi és szülői igények felmérési adataiból indultunk ki az online neveléssel kapcsolatban. A következő táblázat erre ad válaszokat.

\section{5. táblázat}

Óvodapedagógusok és a szülók véleménye az online nevelésrôl

\begin{tabular}{|l|l|l|}
\hline \multicolumn{1}{|c|}{$\begin{array}{c}\text { online térbeli óvodai } \\
\text { nevelés }\end{array}$} & \multicolumn{1}{|c|}{ óvodapedagógusi válasz } & \multicolumn{1}{c|}{ szüi válasz } \\
\hline igényli & $93,5 \%$ & $85,6 \%$ \\
\hline nem igényli & $6,5 \%$ & $6,8 \%$ \\
\hline nem tudja megítélni & 0 & $7,6 \%$ \\
\hline
\end{tabular}

A táblázat adatainak összehasonlítása azt mutatja, hogy a válaszadók többsége az online térben is igényli a gyermekével való foglalkozást (összesen 7,9\% eltérés van a vélemények között). A nemleges válasz esetében még minimálisabb az eltérés $(0,3 \%)$.

A szülők közül páran a „nem tudja megitélni” szöveget jelölték meg (7,6\%), aminek többféle oka lehet: bizonytalanság, ami sok felnőttben jelen van az IKT kisgyermekkor használati tevékenyégekkel kapcsolatosan (például: Otthon eddig erősen korlátozták a digitális eszközhasználatot, most éppen a pedagógusok kérésére kezdik el rendszeresen alkalmazni.

Gondoljunk arra, hogy napjainkban mit látnak, hallanak, érzékelnek a gyermekek a családi élet mindennapjaiban. A gyerekek körül élő felnőttek 
nem mindig figyelnek arra, hogy szavaik és cselekedeteik azonnal hatnak az óvodáskorú gyerekekre, azok tanulási folyamataira. A bezártság, a mozgáshiány, a szabadsághiány negatívan hat az óvodás fejlődésé re. Amikor a gyerekek negatívumokkal élnek együtt, akkor csökken a hosszú távú memória fejlődését segítő tanulási képességük, érzékenyen reagálnak, félelmeik felerősödnek, feleslegesnek érzik magukat. A megszokott napirendi programok felborulása bizonytalanságot idéz elő. Az életmódbeli változások tehát kihatnak a gyerekek fejlődésére. A pandémiás helyzetben az óvodai megszokott szabályok is eltüntek. Az óvodapedagógus más szituációban jelent meg a gyerekek életé ben, és másképpen is viselkedett.

Vegyük sorba milyen tevékenységi területeket tudtak ajánlani az óvodapedagógusok az óvodabezárások idején, és ezt mennyiben azonosították be a szülők?

\section{6. táblázat}

Pedagógiai ajánlások és szülői megitélések

\begin{tabular}{|l|c|c|}
\hline \multicolumn{1}{|c|}{ tevékenységi területek } & $\begin{array}{c}\text { óvodapedagógusok aján- } \\
\text { lásainak aránya }\end{array}$ & $\begin{array}{c}\text { szülők tevékenységbeli } \\
\text { megitélésének aránya }\end{array}$ \\
\hline játék & $89,3 \%$ & $68,9 \%$ \\
\hline szabad tevékenységek & $69,6 \%$ & $48 \%$ \\
\hline mesélés, verselés, bábozás & $94 \%$ & $82,3 \%$ \\
\hline kreatív alkotó tevékenységek & $97,4 \%$ & $91,1 \%$ \\
\hline ének, énekes játék & $90,4 \%$ & $80,3 \%$ \\
\hline $\begin{array}{l}\text { környezó világunk tevé- } \\
\text { keny megismerése }\end{array}$ & $95 \%$ & $79,1 \%$ \\
\hline mozgás, torna & $87,9 \%$ & $70,9 \%$ \\
\hline $\begin{array}{l}\text { szabályok, szokások napi- } \\
\text { rend }\end{array}$ & $27,3 \%$ & $28,2 \%$ \\
\hline
\end{tabular}

A táblázat adatai azt mutatják, hogy többségében az óvodapedagógusi tevékenységi arány kicsit magasabb besorolási szintet mutat, mint a szülői értelmezések. Ezek a különbözőségek nem okoznak problémát, a lényeges , hogy látják a szülők az óvodai tevékenységi rendszerek tartalmi elemeit.

A szülők még számtalan tevékenységeket jeleztek vissza, amit ajánlottak számukra az óvodapedagógusok. Például: memória játékok, iskolaelőkészítő foglalkozások, nemzetiségi nyelvi nevelés, logikus gondolkodás fejlesztése, nyelvtörők, matematikai feladatok. Gondoskodással, felelősségvállalással kapcsolatos témák is felkerültek, és volt, amikor közösen sütöttek, és néha a szülők külön anyagokat kaptak.

Az óvodapedagógusok részéről további tevékenység ajánlások is szerepeltek a szülők számára: nyelvtörők, találós kérdések, hittan, fejlesztő tevékeny- 
ségek, fejlesztő játékok, saját készítésű online játékok, puzzle, matematikai tartalmú tevékenységek, zenehallgatás, közös játékok, színházi előadás, drámajátékok, szülőknek szóló könyvajánlás és gyermeknevelési cikkek, egészséges életmóddal kapcsolatos tartalmak, karanténhelyzettel kapcsolatos javaslatok.

Volt azonban olyan óvoda is, ahol semmilyen tevékenységet nem ajánlottak az óvodapedagógusok a gyerekeknek és szülőknek, illetve csak témákat raktak fel mindenféle iránymutatás nélkül.

Az „iskolaelőkészítő feladatok” megfogalmazás is több válaszban szerepelt, mint ajánlott tevékenység. A megfogalmazás még mindig sokszor elhangzik a szakmai nyelvezetben, a társadalmi diskurzusban, ezért lényeges kiemelni, nem az iskolára való nevelés folyik az óvodában, hanem az életre nevelés - az életkori sajátosságoknak és fejlettségi szintnek megfelelően. Az egyéni bánásmód alapján a kompetenciák alapjainak a lerakása a mérvadó. Ennek érdekében kell megfogalmazni a fejlesztési területeket, összegyüjteni a játékokat, komplex tevékenységi tartalmakat, kialakítani az egyéni fejlödési utak kimunkálását. Egy-egy részképesség kiesésének felismerésével, az elmaradások feltárásával, vagyis a fejlődés nyomon követési eszközeivel és módszereivel tudnak ebben segítséget nyújtani például az óvodapedagógusok vagy a fejlesztő pedagógusok . Ezért lenne érdemes a képzett szakemberek ajánlásait mérlegelni és elfogadni.

\section{Az óvodapedagógusok felkészültsége és a pedagógiai tevékenységek megvalósítása}

Meghatározó erővel befolyásolta a tevékenységek tartalmát, az eredményességet, a sikerélményt, a kudarcot, az az állapotérzés, hogy milyen felkészültséggel kezdték meg az új feltételek mellett otthonról a nevelési feladatok megvalósítását az óvodapedagógusok. Volt, aki a múltbeli tapasztalatokra épített, volt, aki az elsajátított IKT-eszközhasználat és módszertan gyors felidézésével alakította ki ajánlásait, és volt aki a már bevált, régebbi hagyományok továbbvitelét igazította a kialakult helyzetekhez. Ezek mellett meghatározó erővel volt jelen a vezetői elvárások megvalósítása, valamint a kényszerhelyzet szülte kreatív pedagógusi önmegvalósítás megjelenése.

$\mathrm{Az}$ óvodapedagógus nevelőmunkáját nagyban befolyásolja, hogy milyen korosztállyal és milyen fejlettségű szinten lévő gyermekekkel foglalkozik. A felmérésben részt vett kollégák homogén, részben osztott és osztott csoportokban dolgoznak. Az óvodai csoport szervezési adatok jól tükrözik a hazai csoportszervezési hagyományokat. Osztatlan csoportban dolgozók száma a legmagasabb (46,2\%). Ezt azért pozitív adat, mert a teljesen vegyes csoportban folyó pedagógiai munka nagy rugalmasságot és igen differenciált bánásmódot igényel, és az ilyen csoportban dolgozó óvodapedagógusok erőssége jól szolgálja a megváltozott körülményekhez való igazodást, az újító, nem megszokott tevékenységek szerinti szervezést. Részben osztott csoportban dolgozók aránya $(18,1 \%)$, homogén csoportoké a kétszerese $(35,7 \%)$. 


\section{7. táblázat}

Pedagógusi felkészültség és önértékelés aránya

\begin{tabular}{|l|c|c|}
\hline Óvodapedagógusok önértékelése a szakmai felkészültségről & N=fö & Százalék \\
\hline megfelelőnek ítélték meg módszertani felkészültségüket & 903 & $70,1 \%$ \\
\hline akadtak nehézségeik a megvalósítás során & 336 & $26,1 \%$ \\
\hline nem volt megfelelő a módszertani felkészültségük & 49 & $3,8 \%$ \\
\hline
\end{tabular}

A táblázat adatai szerint az óvodapedagógusok majdnem 3/4 része módszertanilag jól felkészültnek tartja magát a pandémia okozta kihívások esetére is. Az tény, hogy az elmúlt 30 évben többféle szervezésű és tartalmú továbbképzés közül válogathattak az óvodapedagógusok, valamint cikkek, könyvek, konferenciák foglalkoztak az online eszközök és módszerek alkalmazási módjaival. A 7. táblázat bemutatja a felkészültségi állapot és megvalósítási módok sokféleségét. Tehát van teendő az alapképzés és a továbbképzések terén a diffrenciált, gyermekre szabott egyéni fejlesztési utak kialakításának segítése érdekében. Ezt erősiti a 8. táblázat ban foglalt megállapítások adatsora .

\section{8. táblázat}

Pedagógusi felkészülés tartalmi különbözőségei

\begin{tabular}{|l|c|}
\hline \multicolumn{1}{|c|}{ A felkészülés különböző útvonalai } & Százalék \\
\hline A neten található tevékenységek közül tudtam megfelelőt választani & $86,4 \%$ \\
\hline $\begin{array}{l}\text { Túl soknak találtam az ajánlatokat és nehéz volt keresni megfelelő tar- } \\
\text { talmakat }\end{array}$ & $12,9 \%$ \\
\hline Saját készítésű tartalmakat, tevékenységeket valósítottam meg & $73,6 \%$ \\
\hline $\begin{array}{l}\text { Az eddig használt módszerekkel, eszközökkel valósítottam meg a fel- } \\
\text { adatokat }\end{array}$ & $26,4 \%$ \\
\hline
\end{tabular}

Arra kérdésre, hogyan készültek fel az óvodai nevelési feladataik ellátására a pandémia alatt, többféle választ jelölhettek egyszerre az óvodapedagógusok. Kettő magas adatot mutat a 8. táblázat. A net, mint "tálca”, sok ajánlást ad a hozzá értő óvodapedagógusnak (86,4\%), és a hozzájuk tartozó gyerekek fejlettségét ismerve így lehetőségük van megfelelő eszközt és módszert kiválasztani és alkalmazni. Majdnem ugyanilyen magas arányt mutat azok száma, akik egyéni tartalmakat készítettek (73,6\%), saját tudásuk alapján alkottak. Ezzel kapcsolatban a kérdésekre adott válaszaik is ezt tükrözik: alátámasztják azt az elméleti tézist, hogy az alkotó, kreatív óvodapedagógus - ha hagyják dolgozni, kiteljesedését éli meg, hatékonyabban és eredményesebben tudja megvalósítani az óvodai nevelés alapvető céljait. Erről adnak képet a 9. táblázatban összegzett óvodapedagógusok önértékelési vallomásai: 
A Covid19 járvány okozta életmódbeli változások hatásai az óvodahasználókra - Óvodapedagógusok és szülők tapasztalatainak áttekintése

\section{9. táblázat}

Óvodapedagógusok véleményei a saját készitésü online tartalmakról

\begin{tabular}{|l|c|}
\hline \multicolumn{1}{|c|}{ Óvodapedagógusi vélemények } & Százalék \\
\hline „hasznosnak tartom , amit létrehoztam ” & $52,4 \%$ \\
\hline „szülői visszajelzések szerint is nagyon fontos” & $51,1 \%$ \\
\hline „ezt kedvelték legjobban a gyerekek” & $34,3 \%$ \\
\hline „szeretek saját készítésű eszközökkel dolgozni” & $28,9 \%$ \\
\hline „hitelesebben tudom bemutatni” & $32,3 \%$ \\
\hline „kihívásnak tekintem” & $32,6 \%$ \\
\hline „nem tartom fontosnak az egyéni módszerek alkalmazását” & $7,1 \%$ \\
\hline „teljesen feleslegesnek tartom” & $2,1 \%$ \\
\hline
\end{tabular}

A táblázat első hat állítása elfogadó, támogató szerepet tulajdonít a saját eszközhasználatnak. A többség hasznosnak tartja saját készítésű online tartalmak létrehozását a pandémia idején . Az utolsó két kérdésre adott válaszok aránya még a $10 \%$-ot sem éri el (7,1\% és 2,1\%), tehát elmondhatjuk, hogy a válaszoló óvodapedagógusok nagy arányban fontosnak tartották saját készítésű tartalmak létrehozását.

A felmérésben a tervező munkában történt változásokra is kiemelten figyeltünk, erre adnak választ a 10. táblázat adatai.

\section{0. táblázat}

Az óvodapedagógusok véleménye saját pedagógiai tervező munkájukról

\begin{tabular}{|l|l|}
\hline \multicolumn{1}{|c|}{ Óvodapedagógusi online pedagógiai tervező munkája } & \multicolumn{1}{|c|}{ Százalék } \\
\hline $\begin{array}{l}\text { Eredeti terv szerint dolgozott, de kicsit változtatott, hogy megfeleljen az } \\
\text { online tevékenységeknek }\end{array}$ & $80,7 \%$ \\
\hline Tartotta magát az eredeti tervhez & $12,4 \%$ \\
\hline Nem az eredeti tervnek megfelelően dolgozott teljesen új tervezéssel t & $6,9 \%$ \\
\hline Kötelező jelleggel ajánlott tevékenységeket & $0,4 \%$ \\
\hline Választhatóság biztosításával ajánlott tevékenységeket & $98,1 \%$ \\
\hline Szülői módosíthatóság lehetóségével ajánlott tevékenységeket & $38,7 \%$ \\
\hline Hetente egy - két tevékenységet sz ervez & $5,1 \%$ \\
\hline Hetente 3-4 tevékenységet szervez & $15,9 \%$ \\
\hline Hetente 5 vagy több tevékenységet is szervez online térben & $56,1 \%$ \\
\hline $\begin{array}{l}\text { Változó, témától függ, hogy mikor milyen gyakorisággal szervez tevékeny- } \\
\text { séget }\end{array}$ & $22,4 \%$ \\
\hline
\end{tabular}

Színes a kép, elmondható, hogy a változtatási lehetőségeket tartalmazó kérdések kapták a legmagasabb értéket (38,7\% és 98,1\%). Ez mutatja az óvo- 
dapedagógusok rugalmasságá $t$, az igazodás fontosságát. Vagyis az igényekhez igazodás képességét, ami meghatározó jelentőségű az óvodai nevelési folyamatokban. A 178 egyéni véleményből kiemelt néhány jellemző gondolat arra mutat rá, hogy a tervező munka során az óvodapedagógusok partneri szakmai kapcsolatai , milyen nehézségekbe ütköztek:

„Csak egyikünk dolgozott távmunkában. A párom ügyeletet vállalt, azIKTeszközök használatának ismeret-hiánya miatt.” „Kolléganöm nincs fenn a Facebook-on, és Messengeren sincs. A heti tervezetét elküldte nekem e-mailben, én pedig megszerkesztettem belöle, amit feltöltöttem a csoportunk F acebook oldalára." „Nincs ugyan váltótársam, de a velem dolgozó pedagógiai asszisztens, dajka is értékes gondolatokkal gazdagitotta a javaslataimat." "Kolléganőmet saját gyerekei leterhelték, így egyedül csináltam mindent.” "Heti váltással készültünk.” „(Úgy dolgoztunk, ahogyan) k ötelezett rá a vezeto””.

A szöveges megjegyzésekből megállapítható, hogy az óvodapedagógusok feladatvállalása heterogén képet mutat. Az elvárásoknak való megfelelés, adott óvodákban rendelkezésre álló körülmények mássága befolyásolta az eredményességet, sokféle megoldást indukált. Mindezek mellett érdemes a szülők véleményének összegzését is elemezni. (11. táblázat)

\section{1. táblázat}

A szülók véleménye az online óvodai nevelés tartalmi ajánlásaival kapcsolatban

\begin{tabular}{|l|c|}
\hline \multicolumn{1}{|c|}{ Szülők véleménye az óvodapedagógusi ajánlásokról } & Százalék \\
\hline $\begin{array}{l}\text { „igen, elegendő tevékenységeket ajánlott az óvodapedagógus, tudtam } \\
\text { válogatni” }\end{array}$ & $79 \%$ \\
\hline „túl sokat küldött” & $10,7 \%$ \\
\hline „nem kaptam anyagokat” & $2,5 \%$ \\
\hline „nem volt gyermekem számára megfelelő a küldött anyag” & $4 \%$ \\
\hline „kevésnek találtam a küldött anyagokat” & $6,2 \%$ \\
\hline
\end{tabular}

A szülők elégedettek voltak az óvodapedagógusok által küldött szakmai anyagokkal (79\%). A válaszokban a tanulási tevékenységek vannak túlsúlyban, az alapkészségek fejlesztése érdekében, sajnos a szabad játék, és annak fejlesztő hatása itt nem került kiemelésre a nevelés folyamatában.

387 szöveges szülői kiegészítő válasz érkezett az online óvodai nevelés tartalmi ajánlásaival kapcsolatban, melyek elfogadó és elutasító véleményeket egyaránt tartalmaznak.

Az elfogadó véleményekből kiemelések: „Új verseket tanultunk, több témakörröl beszélgettünk a feladatok kapcsán, rengeteget rajzoltunk.” „Kisfiam szivesen végzi az ajánlott gyakorlások nagy részét, és ez szerintem lelkesebbé teszi."

„Életkorának megfelelö tartalmakat kaptunk, versek, mondókák, zenés mesék, énekek formájában.” „Mintha az oviban lennénk napi szinten két fog- 
lalkozás van. Tudás bövitése, képességek gyakorlása.” „Az egy-egy téma köré felépitett feladatok, dalok, versek jobban érdeklik a gyerekeket."

"A kreatív ötletek, mesék, versek fejlesztették a nagy-és finommozgásokat, a szókincset, figyelmet, koncentrációt, hogy csak néhányat emlitsek meg a sokrétü feladatok közül.” "(A gyerekek) olyasmit is csináltak, amit egyébként itthon nem szoktak, például sokkal többet kézmüveskedtünk itthon, mint eddig." „Igen, maximálisan sikerült egyben tartani a kis csapatot! Sok, számomra is új technikával találkozhattunk, sok móka és kacagás volt a tornák alatt is.” „Jó ötleteket merítettem, mind lakáson belüli mozgáshoz, mind kreatív elfoglaltsághoz. Illetve talán még fontosabb, hogy gyakran megmagyarázták, mit fejleszt, miért hasznos egyik-másik dolog. " „Olyan kreatív feladatokat küldtek, melyeket én nem tudtam volna kitalálni. A videós mesék pedig egészen testközelbe hozták az Óvónéniket.” „Hittan anyagokat nagyon jól tudtuk használni, de a kreativitás, finommotorika is fejlödött."

A szülői negatív tapasztalatokat leíró vélemények - az online óvodai nevelés tartalmi ajánlásaival kapcsolatban - indoklásokat is tartalmaznak arról, hogy miért nem vették figyelembe, miért nem építették be az otthoni napirendbe az ajánlott online óvodapedagógusi ajánlásokat.

„Mintha egy módszertani kézikönyvet olvastam volna, sok gyakorlati dolog nem volt benne.” „Sajnálatos módon az óvónö szerepet a 8 órás munka mellett képtelen voltam betölteni. Mert a munkahely, minden eddigit meghaladó módon nagyobb terhet rótt ránk. Az online foglalkozások pedig pontosan akkor kívánták volna meg a jelenlétemet, amikor a munkahely is... Engem frusztrált az óvoda digitális jelenléte. Mivel a gyermek sem szerette, onnantól kezdve elengedtem a csoportfoglalkozásokat."

„A home office és a nagyobb testvér digitális oktatása mellett kevés időnk maradt az ovissal feladatozni (...) azt gondolom jobban fejlödött attól, hogy a nagytestvérével játszott, itthon közös élmények érték stb. Fejlödés szempontjából egyáltalán nem számitott az a pár feladat, amit az óvodából küldtek." „Nem küldtek semmit, minden feladatot én találtam ki netröl.” „Néhány linket Facebook csoportban hébe-hóba nem neveznék igazi kapcsolattartásnak."

Fontos hangsúlyozni, hogy az otthoni környezetben a munka világának és az óvoda világának/ illetve az iskola világának a beillesztésére nem volt felkészülve a család. Sem a gyerekek, sem a szülők.

Tudomásul kell venni, hogy a hirtelen életmódváltozás, a helyi megszokások felborulása nagyon komoly szervezési és szemléletbeli változtatást igényel. A napirend egészen más elvek alapján kell, hogy biztosítsa minden családtag önálló életterét, és nem olyan életmódot kell kialakítani, mint például a szabadság alatt. Otthon van mindenki, és mégis másféleképpen kell élni. Ennek kialakítására nem volt idő, a bezárás gyorsan jött, és ez az, amivel elsődlegesen kell foglalkozni - mivel a feltételteremtés az alapja a nyugodt, kiegyensúlyozott és eredményes együttélésnek.

Az óvodapedagógusok ajánlásainak fogadtatását összegeztük az óvodapedagógusok és szülők véleménye alapján a 12. táblázatban. 


\section{2. táblázat}

Az online óvodai nevelés tartalmi ajánlásai alapján megvalósított gyermeki tevékenységekröl adott pedagógusi és szülői vélemények

\begin{tabular}{|l|c|c|}
\hline \multicolumn{1}{|c|}{ A javasolt gyermeki tevékenység } & $\begin{array}{c}\text { pedagógusok } \\
\text { véleménye }\end{array}$ & $\begin{array}{c}\text { szülői vélemé- } \\
\text { nyek }\end{array}$ \\
\hline van, amikor érdekelte, aktív volt, van, amikor nem & $67,3 \%$ & $63,3 \%$ \\
\hline érdeklődve figyelt egy darabig, aztán otthagyta & $5,3 \%$ & $25,8 \%$ \\
\hline csak figyelt, szemlélődött & $5,1 \%$ & $6,9 \%$ \\
\hline $\begin{array}{l}\text { nagyon várta, hogy mi fog történni - változó } \\
\text { érdeklődéssel }\end{array}$ & $26 \%$ & $23,2 \%$ \\
\hline kérte, hogy kapcsoljuk be a gépet & $0 \%$ & $10,3 \%$ \\
\hline érdeklődve figyelt & $16,5 \%$ & $44,9 \%$ \\
\hline hozzászólt a témához & $0 \%$ & $19,6 \%$ \\
\hline rá kellett beszélni & $0 \%$ & $11,6 \%$ \\
\hline egyáltalában nem érdekelte & $14,1 \%$ & $12,2 \%$ \\
\hline nem figyelt, noszogatni kellett & $0 \%$ & $5 \%$ \\
\hline nem lehetett megítélni & $10,9 \%$ & $5,9 \%$ \\
\hline $\begin{array}{l}\text { megjegyzés: Az óvodapedagógusok nem tudtak minden kérdésre válaszolni, mert nem } \\
\text { voltak egy térben a gyerekekkel, a szülők tudták gyermeki reakciókat pontosan megfogal- } \\
\text { mazni. }\end{array}$ & \\
\hline
\end{tabular}

A 12. táblázat részletes képet ad a gyermeki hozzáállás é s viselkedés szülők által tapasztalt oldaláról. A várakozás, az érdeklődés és a figyelem aránya biztató, a szemlélődés is. Természetesen a figyelem elkalandozásának sokféle oka lehet, a helyi körülmények meghatározó erővel befolyásolják ennek mértékét, amiről nincsenek információink. A s zülők véleményét jól tükrözik és árnyalják a táblázaton kívüli adatok egyarnt : 79\%-uk gondolja úgy, hogy kaptak megfelelő segítséget az óvodapedagógustól az online óvodai időszak alatt, ezért tudtak válogatni az ajánlatokból . A szülők 54\%-a szerint túl sok elvégzendő tevékenységet küldött az óvodapedagógus, ami befolyásolta az otthoni napi életet, zavarta a családot. A szülők $3 / 4$ része $(75,3 \%)$ jelezte, hogy a kapott ajánlott tevékenységek segítették gyermekük fejlődését.

A szülők a következő területeken éreztek előbbre lépést óvodáskorú gyereküknél az online óvodai időszak alatt: finommotorika, kézügyesség, eszközhasználat (például olló használata) türelem, beszéd (például online logopédiai fejlesztés és szókincs), önbizalom, képzelőerő, valamint a mozgás tevékenységek során. Eredményeink árnyalt értelmezéséhez kiemeltünk konkrét szülői véleményeket a szülők megfogalmazásait használva. Láthatóak az egymással vitázó vélemények, a különbözően értelmezett tapasztalatok. 
„Hiába a sok feladat, úgy érzem nem fejlödött úgy (itthon), mint az oviban. Hiányoznak a társas kapcsolatok, a csapatszellem, a húzóerő. Óriási kiesésnek érzem ezt a fél évet. Az óvodai pedagógusok mindent maximálisan megtettek, még többet is, mint elvárható."

„Direkt kiemelték, hogy ezek csak ajánlások, semmiképp ne eröltessük, csak, amihez kedve van. Ez nekem nagyon szimpatikus volt. 3-4 éves gyerekekröl van szó. Volt, amit pár nappal később csináltunk meg, mert akkor volt hozzá kedve.”,Sajnos nem volt kötelezö semmi.” „Elfogadtam és megcsinálta a gyerek. Néha kisebb-nagyobb rábeszélés kellett a gyereknek, hogy megcsinálja, de mindig elkészitette, amit kértek.” „Az óvodától nem a gyerekmegörzést várjuk akkor sem, ha normál müködés van. Itthon sem bántam, hogy vannak kötelezők.” „Örültünk volna, ha kapunk feladatokat, vagy egyáltalán némi érdeklödést a pedagógustól."

Összegezve igen heterogén a kép az adatok és az írásos vélemények alapján. Ez természetes, mivel az érintettek az átélt tevékenységek alapján tudták megítélni az ajánlások eredményességet. Az óvodapedagógusok munkájában módszertani téren van, ahol újítások is találhatók, de alapvetően a régi módszereik élnek. A feladatadás dominanciája - sajnos -, megfigyelhető mind a szülők, mind az óvodapedagógusok szemléletében. A játékban, kiemelten a szabad játékban való spontán tanulás fontossága nem kapja meg a jelentőségéhez képesti megfelelő teret a válaszok elemzése alapján.

Az online eszközök célszerű alkalmazásának kialakításához, az új életmód folyamatába való beillesztéséhez helyi családismereti, partneri együttmüködési lehetőségek kialakítására egyaránt szükség volt, illetve lett volna. Alapos átgondolást igényel a szülőknek való tevékenység ajánlása során a mikor, mit és mennyit differenciált átgondolása. Mindig két oldalról kell átgondolni a tervezést, szervezést és megvalósítást. A z óvodapedagógus felkészültsége és gyermekismerete illetve, a szülői nevelés megismerése egyaránt lényeges eleme a folyamtnak. Egyenrangúan lényeges a szülő hozzáállása és lehetőségei. A felmérésben kiemelt hangsúlyt kapott az egyéni bánásmódra, a differenciált tevékenység ajánlásra való odafigyelés.

\section{3. táblázat}

Egyéni beszélgetések a gyerekekről

\begin{tabular}{|l|c|c|}
\hline \multicolumn{1}{|c|}{$\begin{array}{c}\text { Az egyéni beszélgetési lehetőségek } \\
\text { megvalósítása }\end{array}$} & $\begin{array}{c}\text { óvodapedagó- } \\
\text { gusok válaszai }\end{array}$ & szülők válaszai \\
\hline volt gyerekre irányuló egyéni beszélgetési lehetőség & $26,1 \%$ & $26,8 \%$ \\
\hline $\begin{array}{l}\text { nem volt gyerekre irányuló egyéni beszélgetési } \\
\text { lehetőség }\end{array}$ & $13,1 \%$ & $39,8 \%$ \\
\hline $\begin{array}{l}\text { gyereknek adott vagy kért egyéni tevékenység-ajánlást } \\
\text { gyereknek nem adott vagy nem kért egyéni tevé- } \\
\text { kenység-ajánlást }\end{array}$ & $32,9 \%$ & $42,9 \%$ \\
\hline nem éltek az egyéni beszélgetés lehetőségével & $23,8 \%$ & $20,8 \%$ \\
\hline
\end{tabular}


A 13. táblázat adatai vegyes képet mutatnak az óvodás gyermek körül lévő szülők és óvodapedagógusok egyéni beszélgetési igényeiről az online óvodai időszakban. Mindig fontos cél erősiteni a nevelőpartneri viszony , az együttnevelés fontosságának erősítése, erre szükséges építeni a jövőben is nagyobb odafigyeléssel az egyéni bánásmód tartalmi megvalósítása érdekében.

Egy következő kérdésbe $n$ az egyéni beszélgetések kezdeményezési igényét tárták fel az adatok. Az óvodapedagógusok szerint szülői kezdeményezésre jött létre az egyéni beszélgetés a legtöbb esetben $(81,2 \%)$, az óvodapedagógusok kevesebbet kezdeményeztek (66,7\%), mint a szülők, és az óvodavezetők kezdeményezték a legkevesebbet $(5,1 \%)$ a beszélgetéseket. Érdekes adat, hogy a gyerekek is kezdeményeztek beszélgetéseket (29,6\%). A lehetöség, az igény és szükségszerüség összhangjának megteremtése vihetné előbbre az egyéni bánásmód szélesebbkörủ gyakorlati alkalmazását . A kutatás tapasztalatai szerint az óvodapedagógusok mindennapi pedagógiai munkájában az online időszak alatt is a csoportban való gondolkodás tapasztalható. Pedig az életmódbeli változás, és a sokféleség a gyermekek fejlődési folyamatai ban igényli az egyéni tervezést, és ezáltal az egyéni módszerek alkalmazását a pedagógiai folyamatokban, valamint a kapcsolattartási módokban.

A fogadó órák évek óta rendszeresen megvalósulnak az óvodákban. Sokszor behívják az óvodapedagógusok a szülőket, hogy a gyerek egyéni fejlődéséről, nevelési kérdésekről beszéljenek, szülök is nagy arányban kezdeményeznek beszélgetéseket. A pandémia alatti intézménybezárások idejéén a személyes beszélgetéskeről nem lehetett szó, de adatainkból látható, hogy erre igény van, és szükséges is a partneri együttnevelés érdekében, a sajátos nevelési igényü gyermekek és szüleik esetében még inkább. A differenciált egyéni bánásmód megvalósítása érdekében szükség van az egyéni beszélgetésekre, a család és az óvoda kapcsolat tartási módjainak korszerüsítésére a mai kor eszközeinek célszerű felhasználásával (például online platformok szinkron használata).

\section{Kapcsolattartás}

Az online kapcsolattartási eszközök használatáról ad képet a 14. táblázat.

\section{4. táblázat}

A kapcsolattartás módja család és óvoda között az online nevelési időszakban

\begin{tabular}{|l|c|c|}
\hline $\begin{array}{c}\text { kapcsolattartási eszkö- } \\
\text { zök, -módok }\end{array}$ & $\begin{array}{c}\text { óvodapedagógusok vá- } \\
\text { laszai }\end{array}$ & szülők válaszai \\
\hline E-mail & $35,3 \%$ & $23,6 \%$ \\
\hline Messenger & $76,6 \%$ & $53 \%$ \\
\hline Facebook & $82,8 \%$ & $78,8 \%$ \\
\hline Telefon & $43,6 \%$ & $20,5 \%$ \\
\hline Zoom & $1,2 \%$ & említettek \\
\hline
\end{tabular}


A táblázati adatokban „kapcsolattartási eszközként” a Facebook volt a legygyakoribb Kölcsönösséget és partneri viszonyt jeleztek a válaszadó óvodapedagógusok a szülőkkel való együttmüködés minőségére vonatkozó kérdésnél $(78,3 \%)$.

A szülők kiegészítésként a következő kapcsolattartási módokat sorolták még fel: Zoom, Google Drive, Google Classroom, Viber, Padlet, weboldal, Skype., óvodai honlap, papirra nyomtatott feladat ok, amit kitöltve személyesen adtak le az óvodában.

Az óvodapedagógusok az alábbi kapcsolattartási módokat jelölték még meg: óvodai honlap, Google Classroom, Google Meet, YouT ube, Blog, WhatsApp, Google fotók, videófelvételek, az ajánlott játékok papíron való eljuttatása videó beszélgetés szervezése, Google levelezöcsoport létrehozása. Személyes látogatás is elöfordult. Szerepeltek még: Zoom, Google Drive, Viber, Padlet, Skype használata kisebb arányban. Az online óvodai nevelés időszakának kapcsolattartási tapasztalataira vonatkozó szülői véleményekből vett idézetek szintén árnyaltan mutatják meg a kialakult helyzet megélését.

„Nekünk óriási segítség és kapaszkodó volt, hogy „nem engedték el a kezünket.” "Segített kialakitani egy újfajta mindennapi rutint a lányaim számára, jó volt látni, hogy az ovis társak hogyan valósitják meg a teendöket és jól estek az óvó nénik mindenkor kedves, dicsérő szavai." „A kisfiam negyedik éve járt ebbe az óvodába. Amióta új vezetője van (kb. 2 éve), egyre-másra szembesülök azzal, hogy mennyire nem értek egyet az óvoda müködésével: sokszor azt érzem, hogy én szülö vagyok az óvodáért, a szabályaiért, stb, nem pedig az óvoda a gyerekért, pedig szerintem ez utóbbi volna helyes.” „Az óvodapedagógusok részéröl semmiféle igény nem mutatkozott a gyermekekkel történö kapcsolattartásra. A kapcsolattartás - ha egyáltalán ezt annak nevezhetjük - kimerült a napi, zömmel internetről összeollózott ajánlások küldésében.” „Minden elismerésem a gondosan összeállitott, gazdag kinálatért, amit kapunk. Csak azt sajnálom, hogy a munka-háztartás-gyerekek körüli mindennapi feladatok mellett csak a töredékét tudom annak megvalósitani, amit ajánlanak, illetve amit az óvodában kapnának."

Érdekes megvizsgálni az óvodapedagógusok által megfogalmazott mondatokat arról, hogyan élték meg az online időszakban a kapcsolattartást a szülőkkel. 336 fő írt szabad szöveges választ ebben a témában.

„Néhány szülö igényelte a kapcsolatot, és nem kaptunk visszajelzést. Igazából ez nem bánt bennünket a kolléganömmel, de sok kérdőjel maradt így bennünk a kölcsönösséggel kapcsolatban. Vajon igényelték - e ezt a szülök? Az ötleteket, vajon szükség volt-e ránk, több esetben?” „A szülök nem voltak partnerek. Azt gondolom teher volt számukra. Föleg, akinek iskolás gyereke is van.” „Három csoportra tudom osztani. Az egyik: a szülövel nem lehetett felvenni a kapcsolatot, igy nem tudtam a gyermek fejlödését nyomon követni. A második: A szüló belépett a Facebook zárt csoportjába, meg is nézte a posztjaimat, de nem látszott, hogy a gyermek aktiv-e, mert a szülö nem posztolt semmit, illetve nem volt kommunikatív. A harmadik csoport aktívan részt vett az online munkában." 
„Ahol nem volt technikai eszköz, csak telefonon informálódtam.” „Nálunk az óvodavezetö gondolja magát fontosnak, hogy ő küldje a szülönek az általunk megírt heti szakmai tervet darabokban. Tehát akadályozta a kapcsolattartást a szülökkel. De a gyerekeket nem hagyhatom magukra: így a Padlet alkalmazást használva, küldöm a szakmailag komplex játék és tevékenység ajánlást 1 hétre: projektszemlélettel tervezve. Minden szülövel egyénileg tudok így kapcsolatot tartani.” "A vezetö utasítására nem volt egyéni kapcsolattartás.” „A szülőket nem sikerült aktivizálnunk. Hiába igyekeztünk a kolléganömmel olyan saját anyagot összeállitás, ami maximálisan a mi gyerekeinkre szabott, otthon megtalálható, egyszerü anyagokból, olcsón, pedagógiai rutin nélkül is egyszerüen megvalósitható, mégis érdekes, fejlesztö - úgy érzem, legtöbbször el sem jutott a gyerekekhez.” „Hiába támogatom a családok mindennapi életét, ha nem kapok visszajelzést. Mivel ajánlásként adjuk a tevékenységeket, általában nem végzik el. A meséket örömmel vették, de már a dalokat, verseket nem tanulták meg, kevés tevékenységröl kaptam visszajelzést. Egy család örült a rendszeres kapcsolattartásnak.” „Ezen a téren nem éreztem hiányosságot. A szülök sokszor megkerestek kérésekkel, kérdésekkel és problémákkal is. Söt, több családnál azt éreztem, hogy ebben az időszakban sokkal több bizalmas dologgal fordultak hozzám.” „Tilos volt Facebook csoportot létrehozni az óvónőnek önkormányzati utasításra, így a szülök maguk hozták létre a csoportot, amibe az SZMK-s szülö feltöltötte, amit küldtem. Majd a szülök Messengeren küldtek fotót az elkészitett dolgokról vagy kérték a segítségünket."

A szöveges válaszokból kirajzolódik mind a szülők, mind a pedagógusok bizonytalansága. Kíváncsiak voltunk arra is, vajon a kapcsolatok változásait hogyan élték meg a résztvevők. Történt-e változás a kapcsolatok intenzitásában és minőségében az online óvodai időszakban.

A válaszadók kevesebb mint fele, 49\%-a elégedett az óvodával való kapcsolattartási módokkal. Az új kapcsolattartási módok, új eszközök beépüléséhez idő kell, kidolgozott stratégiai tervre és helyi elfogadott speciális igények figyelembevételére egyaránt szükség van.

\section{Következtetések}

A felmérés képet ad a kutató-fejlesztő szakembereknek, óvodafenntartóknak, óvodavezetőknek, óvodapedagógusoknak arról, hogy a megváltozott életmód, életvitel alatt az online óvodai nevelés mit tudott adni az óvodahasználóknak, a szükségleteikre, az igényeikre mennyire és hogyan tudott válaszolni az óvoda, elsősorban az óvodapedagógusok. Arra is sok adat érkezett a szülőktől, hogyan élték meg maguk a gyerekek az eseményeket. Sajátos képet formálhatunk a szülői válaszokból arra vonatkozóan, hogy az online óvodai nevelés időszaka a szülők megfigyelései szerint gyerekeik fejlődésére hogyan hatott. Természetesen eredményeink korlátok között értelmezhetőek, ugyanakkor fontos eredményünk szerint, az online óvodai nevelési idő- 
szak esetében és a személyes jelenléti időszak esetében egyaránt bővíthető a szülőkkel való kapcsolattartás új formákkal, olyan új kapcsolattartási módok megtalálásával, amelyre a családdal való együttnevelés egy szoros, egymásra figyelö partneri kapcsolatban támaszkodhat. Eredményeink alapján erre mind az óvodapedagógusoknak, mind a szülőknek kifejezett igénye van.

Eredményeink szerint az online nevelési időszakban az óvodapedagógusok kevéssé törekedtek az egyéni bánásmód elvének tartalmi megvalósítására, az eltérő, egyéni különbségekre való odafigyelésre.

Lényeges eleme az új helyzetben való helytállásnak, hogy amit vállal az óvodapedagógus, azt meg is tudja valósítani. Az életkörülmények is nagyon befolyásolják a munkavégzést. A tapasztalatokból kiderül, gyümölcsöző az óvodapedagógusok esetében is a személyre szabott munkavégzés megteremtése. Nagyon fontos jelenleg is a rendszeresség és következetesség elveinek elfogadása, erősítése, bizonyos egészségügyi szabályok, napirendi elemek megvalósulása.

Az életmódbeli változások hatásai tettenérhetőek a felmérés adatainak elemzésével. Ezeket csoportosítva az alábbi tények adnak további gondolkodási és fejlesztési útvonalakat a szakemberek számára. A gyerekek körében tapasztalt hatások, tennivalók és eredmények: alkalmazkodniuk kellett a megváltozott helyzetekhez, így önállóságuk gyorsabban fejlődött, önellátásra is többször volt szükség; más-más szokások léptek életbe és kaptak prioritást, amit el kellett fogadni; a bizonytalanság érzése miatt viselkedésük megváltozott, van aki erőszakosabbá, vagy éppen fordítva visszahúzódóvá, magányosabbá vált, érzelmileg labilisabb, bizonytalanabb lett; a félelemmel kapcsolatos hatások erősítették a viselkedés megváltozását (beszéd és mozgásfejlődés elmaradásai)

A szülők körében tapasztalt hatások, tennivalók és eredmények: egy részük jobban megismerte az óvodai hatások sokféleségét, az óvodai nevelés tartalmát; többségük jobban érzékeli és jobban rálát, hogy mire van szüksége gyerekének; rádöbbent, hogy az életmódbeli változásokkal kapcsolatos másfajta családi napirend kell, amit ki kell együtt alakítani a családtagokkal; minden családtagnak biztosítani szükséges az önálló életteret, az óvoda-család kapcsolat fontossága érdekében helyi hálózatépítés szükséges, szülőkszülők újfajta kapcsolati rendszerének kiépítése is indokolt.

Óvodapedagógusok körében tapasztalt hatások, tennivalók és eredmények: bizalom kiépítése és biztosítása szükséges a fenntartótól, vezetéstől az új életmód sikeres megvalósításához; a jól képzett és nagy önállósággal bíró kreatív óvodapedagógus kibontakozása lényeges cél; óvodán belüli és óvodaközi szakmai munkaközösségekre van szükség a tudásfejlesztésre a helyi igények és lehetőségek, valamint szükségletek szerinti tervezéssel, megvalósítással; az egymásra figyelés, másik fél meghallgatása, türelem - az egyéni differenciált bánásmód megerősítése a gyermeki érdekek előtérbe helyezésével hangsúlyos szerepet kap az online térben is; a három oldal kapcsolatépítése - gyermek, szülö, óvodapedagógus - egyéni és közösségi formáinak 
újítására van szükség - korszerü online eszközök bevonásával, illetve a helyi igények és lehetőségek figyelembevételével.

Ajánlások a továbblépés és a másfajta környezeti feltételek közötti óvodai nevelés sikeres megvalósítás érdekében: Az óvodán belül az óvoda dolgozói - beosztásuk és képzettségük szerinti segítséget kapjanak munkájuk megváltozott helyzetekhez való igazítása érdekében. Az egymástól tanulás lehetőségeit kell megteremteni a tanuló szervezet kialakításával. Az óvoda külső és belső kapcsolatainak ápolásában, fejlesztésében és működtetésében igen fontos szerepet játszik a körülmények megváltozása. A helyi feltételek nagy mértékben befolyásoló tényezők, meghatározó a tudásszint, az óvodahasználók körének igényei és szükségletei alapvetőek, és ehhez kell igazodnia a helyi óvodai közösségnek, vagyis közös megállapodás szükséges: ki hogyan, mikor, és milyen eszközzel tud kapcsolódni, milyen szokásrendet tud elfogadni - igy teremthetőek meg az újfajta kapcsolati hálók.

A kapcsolatok formai és tartalmi elemeinek megújulását eredményezheti az informatikai eszközök tárházának céltudatos használata. A zárt Facebook csoportok alakításával a kapcsolat nem csak az óvodapedagógus és szülő, de a szülők közötti kapcsolatfelvételt is biztosíthatja. Mód nyílik egymás megismerésére nem csak a régi módszerekkel (a szülői értekezleten, és a nyílt napokon). A szülők bevonását a nevelőmunka folyamatába szintén szükséges jobban kiépíteni. Modern kapcsolattartási módokkal (Zoom, Skype, Teams) hasznos lehet például módot találni arra, hogy - a munkára nevelés megalapozása érdekében - beleláthatnak egy-egy szülő, családtag munkatevékenységeibe. Ezen élmények felhasználásával a kortársi kapcsolatok alakítását egyaránt pozitívan lehetne befolyásolni. Lehetőségeket kell teremteni a gyerekek számára felidézni a látottakat, felhasználni a kapott élményeket spontán beszélgetések során, vagy éppen élményrajzot készíteni.

Az óvoda külső kapcsolatainak építésében a levelezési tevékenységek igen eredményesen alkalmazhatók az információs eszközökkel. Az óvodák honlapjai képet adnak az óvoda müködésétől kezdve a tartalmi munkájának elemeiről, a tárgyi és személyi feltételeken át egészen az egyes tevékenységi tartalmak bemutatásáig. Sok helyen pár perces videók, színes képek és a képek alá írt szövegek engednek bepillantás az eseményekbe. Azt is mondhatjuk, hogy nyitott könyv lett az óvodán belüli élet a szülők és a fenntartók számára is az online térben.

Összegezve a gyermekekkel foglalkozó felnőttek körének arra kell legjobban törekednie, hogy az érzelmileg legfogékonyabb korban az érzelmi biztonság a bizalom ne sérüljön, hanem még jobban támogató és erős bástya legyen. A közös élmények, a gyerek önálló, nyugodt játékterének biztosítása, más fejlesztő tevékenységek megteremtése is lényeges, nem csak az óvodai nevelés folyamatában, hanem otthon a családban is teret kell, hogy kapjon. Mindezeket az óvodapedagógus és a szülők összefogásával, együtt gondolkodással, felelősséggel lehet megvalósítani. 
A Covid19 járvány okozta életmódbeli változások hatásai az óvodahasználókra

\section{Irodalom}

Bakonyi A. \& Kosztel, K. (2019). Online lehetőségek az óvodában, túl a karantén időszakán. Óvodai Vezetési és Nevelési Módszertani Tanácsadó, 8(11), , 33-44.

Csoma, Gy. (2014). Mire való az andragógia? Szaktudósitó, 09-10, 6-7 .

Kovács, I. ( 2005). Új út az oktatásban? A távoktatás. OKKER.

Villányi, Gy.né (2019). Távnevelési feladatok lehetőségei. A Kisgyermek, 13(5), 27. 


\section{Villányi, Gy.}

\section{The effect of lifestyle changes (experience of kindergarten teachers and parents in 2020)}

An extensive online survey was conducted in the first half of 2020, led by the Early Childhood Education Department of the Hungarian Pedagogical Society (MPT), to map the changes related to the kindergarten closures that came into effect. The survey was made by dr. Bakonyi Anna, Kosztel Krisztina and Villányi Györgyné Jutka. The questions included requests for statistical data, online kindergarten education planning, methodological and implementation methods, as well as exploration of contact and organisational possibilities. In the questionnaires for kindergarten pedagogues and parents, we sought the answer on how they lived and experienced the quarantine, with the new virtual space. We were curious about what feelings and experiences, richer or poorer they got, and in what way we can use its positive part to transfer knowledge we can use later, in everyday kindergarten life. The questionnaire was sent out on Facebook to kindergarten educators on 12th May 2020, 1298 of them filled it until 9th June. The parents filled it between 11th May 2020, and 3rd June, 681 of them.

Keywords: „remote education” in kindergarten, diversity of relationships, lifestyle changes 